\section{Volcanics from the Sierra Leone Rise}

- THE Sierra Leone Rise, located in the east equatorial Atlantic, forms a discontinuous chain of seamounts as shallow as $2 \mathrm{~km}$ extending with a general NE-SW trend from near the Sierra Leone coast of Africa, to the St Paul fracture zone near the Mid-Atlantic Ridge (Fig. 1). The origin of this feature has remained a topic of discussion. Sheridan et al. ${ }^{\prime}$ have hypothesised that the Sierra Leone Rise is a volcanic structure formed at the beginning of the opening of the Atlantic in the early Cretaceous period.|The twin features of the Sierra Leone and the Ceara Rises are probably of oceanic origin and were created 80 Myr ago or later in their present-day position with respect to Africa and South America ${ }^{2}$. The Atlantic ocean exhibits several similar aseismic structures which appear symmetrically oriented with respect to the mid-oceanic ridge, such as the Walvis-Rio Grande Rise and the Iceland Faeroes-Iceland Greenland Ridges. These structures are volcanic edifices having a composition similar to that found in their associated islands ${ }^{3}$ ? Deep sea drilling of the (eara Rise ${ }^{x, y}$ penetrated a basaltic hasement of the upper Cretaceous period (Maestrichtian) (Leg 39, Site 3.54). Similarly, a DSDP hole (Leg 41. Site 366) on the Sierra Leone Rise, penetrated sediments of the same period, without reaching basement ${ }^{10}$. We report here the discovery of alkali-rich volcanics in an area of the Sierra Leone Rise. The sediment overlying the rock fragments is aged $-45 \mathrm{Myr}$.

During the Romancha cruise of the RV Jean Charcot in December 1977 we studied the south eastern slopes of the Sierra Leone Rise, near DSDP Site 366, with the objective of sampling crustal material (Fig. 1). From a detailed bathymetric survey, using a multichannel narrow beam echo-sounder, it was possible to locate the best existing outcrops for dredging. However, despite this, our dredging operation proved unsuccessful, mainly
Table 1 Chemical analyses of material collected from a piston core (CH 77-07) from the Sierra Leone Rise

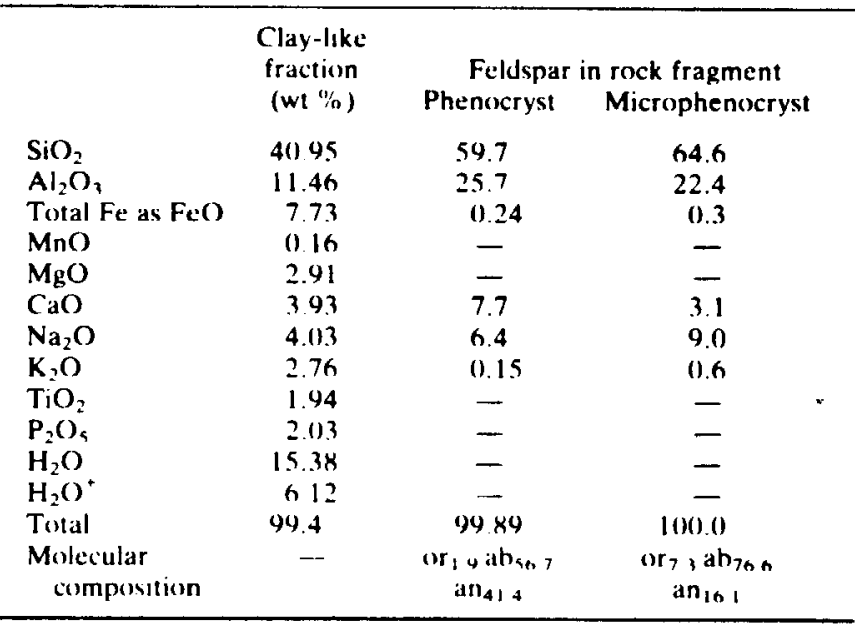

The small clay-like sectuon matrix made up mainly of smectite and zeolite was analvsed by X-ray fluorescence (P. Cambon and J. Etoubleau ). The minerals were determined by energy dispersive analysis of $X$ rays.

because of the topography of the area surveyed, which consists of gently rolling sediment-covered hills having stopes of $<16^{\circ}$.

A sediment core $(1.6 \mathrm{~m}$ long) was taken in the same area (lat $05^{\circ} 14.9^{\prime} \mathrm{N}$; long $20^{\circ} 15.1^{\prime} \mathrm{W}$ ) as the site of the dredging (Fig. 1). This core was recovered from a depth of $2,720 \mathrm{~m}$ near the summit of a seamount, which appeared to be the site of important erosional processes resulting from bottom currents (Fig. 2). This core penetrated a sediment veneer and entered a highly altered basement. The upper levels in the core $(0-67 \mathrm{~cm})$

Fig. 1 Bathymetric map of the Sierra Leone Rise from Uchupi ${ }^{14}$ showing the location of the core $\mathrm{CH} 77-07$ and of the Deap Sea Drilling hole $366^{10}$

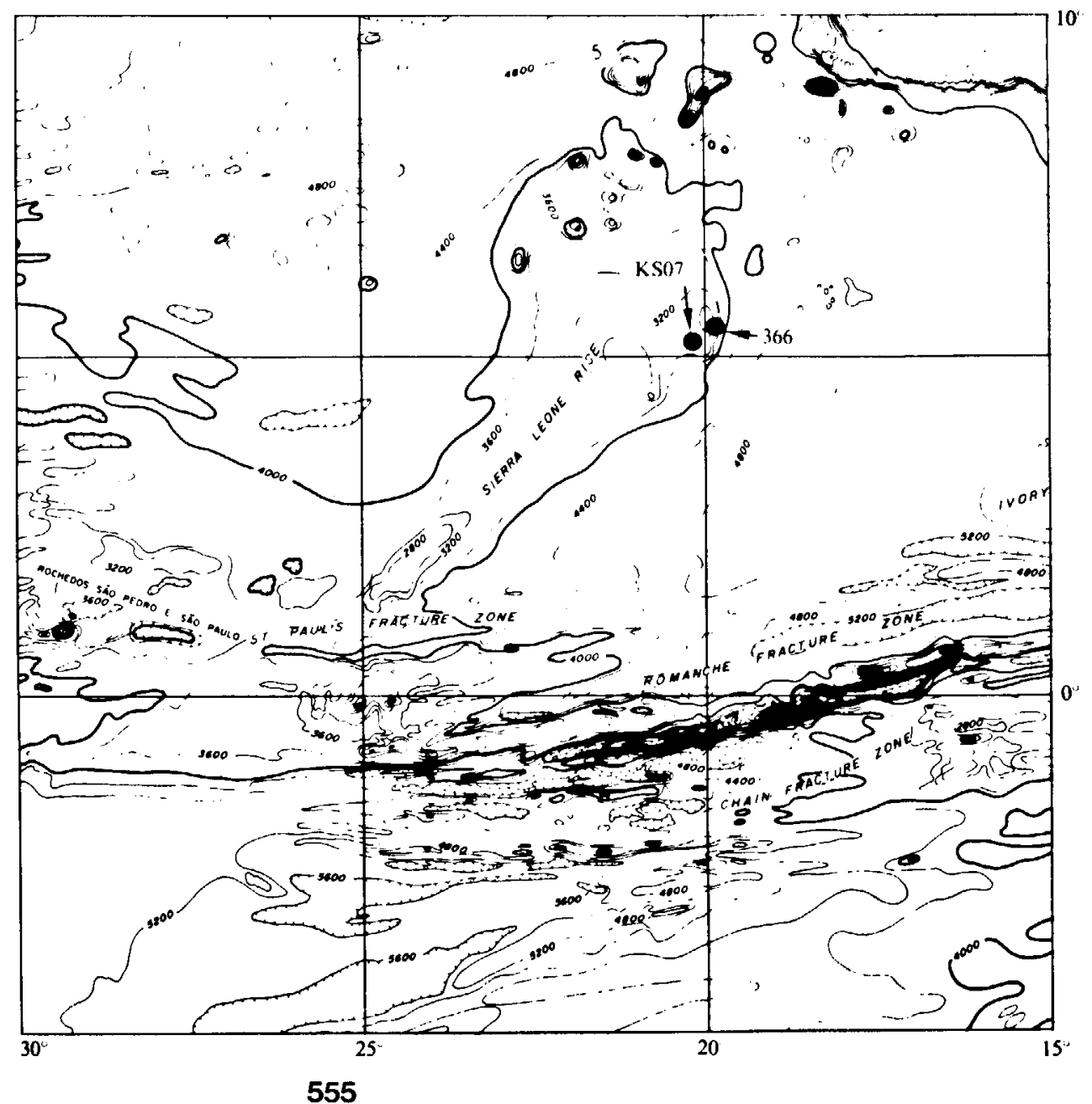


are upper Pleistocene to Holocene in age (NN21-N23) with extensive reworked material as old as middle Eocene, especially from 25 to $67 \mathrm{~cm}$. Despite some disparity between the nannofossil and foraminiferal record, only the Oligocene appears absent. From 67 to $110 \mathrm{~cm}$, the ages range from upper to middle Eocene (about 45 Myr BP) with some upper and middle Paleocene (6) Myr BP) foraminifera observed. From 110 to $130 \mathrm{~cm}$, the sediment is a foraminiferal chalk epigenised to apatite. The biogenic elements include fish remains and unidentified casts of foraminifera. Below $130 \mathrm{~cm}$ no biogenic elements are observed.

The change in mineralogy corresponds to the stratigraphical limits encountered in the core: from 0 to $67 \mathrm{~cm}$ depth in the core, the known carbonate fraction comprising about $15 \%$ of bulk material consists mainly of kaolinite with some smectite and quartz. At $67-110 \mathrm{~cm}$ the smectites forming the main constituents of this level are associated with well-crystallised zeolite of the heulandite type. This latter material is volcanic in origin. Apatite occurs in the lower section of the core at $110 \mathrm{~cm}$. The contact below $130 \mathrm{~cm}$ is made up of a thin $(<0.3 \mathrm{~cm})$ iron manganese lamina overlying a green brecciated clay-rich material. This material consists mainly of soft green clay aggregates intermixed with reddish brown abundantly altered and highly vesicular rock fragments, and scattered grains of clinopyroxene and feldspar with sharp crystalline boundaries. The small fraction is formed of well-crystallised smectite, and two types of zeolites, heulandite and phillipsite, are also present in smaller amounts. This small clay-like fraction has a mean composition relatively high in silica $(41 \%)$, and a high total alkali content $\left(\mathrm{Na}_{2} \mathrm{O}=4 \%, \mathrm{~K}_{2} \mathrm{O}=2.8 \%\right.$ ) (Table 1 ), which is compatible with the mineralogy. The relatively high $\mathrm{P}_{2} \mathrm{O}_{5}$ content $(2.0 \%)$ reflects the presence of apatite needles.

The type of mineral association (pyroxene, feldspar, apatite, smectite and zeolite) is also encountered in the rock fragments ( $\sim 3 \mathrm{~cm}$ diameter) found within the material recovered. These rock fragments consist of early-formed feldspar set in an altered ferrugineous matrix containing pyrite, apatite and tiny laths of parallel oriented feldspar indicating a trachytic textural feature. The feldspars in the rocks are tabular with faint twinning and do not show any signs of secondary replacements. The groundmass is reddish brown due to the extensive alteration, with iron oxide material and smectite being the main alteration minerals encountered. Scanning electron microscope observations show that the zeolites developed in situ in geode-like structures.

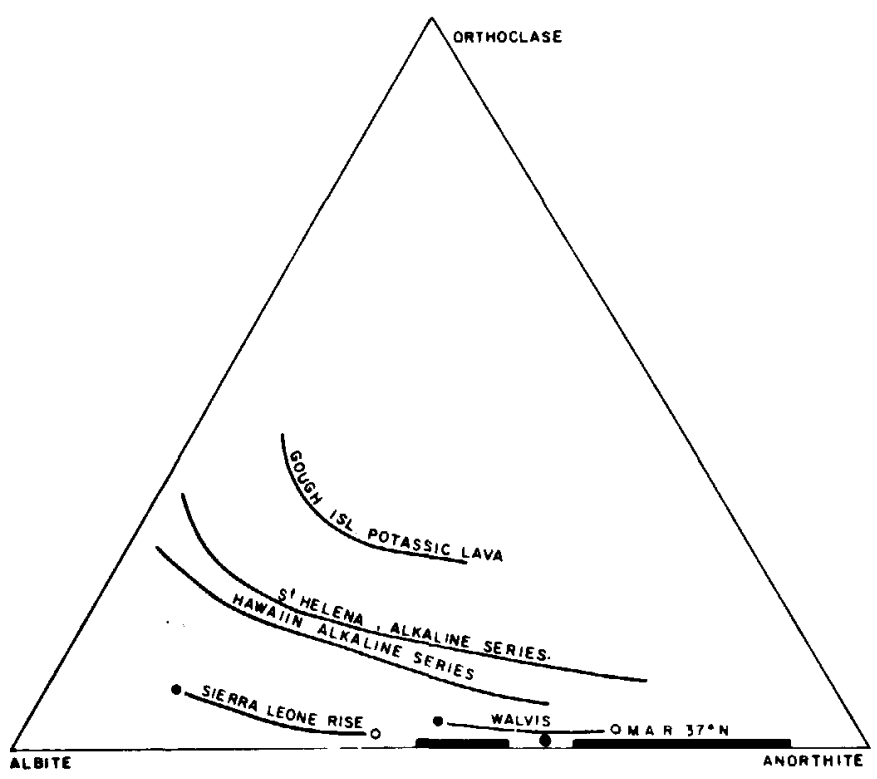

Fie. 3 An-or-ab ternary diagram of feldspar composition from various localities. The data from Gough island ${ }^{15}$, from Hawaii ${ }^{16}$ and from St Helena ${ }^{17}$ we compared with that from the Walvis Ridge and the Sierra Leone Rise. An open circle indicates phenocrysts of analysed feldspar and the filled circles are matrix feldspar found in the corresponding rock samples. The data on the plagioclase from near $37^{\circ} \mathrm{N}$ in the Atlantic ocean were taken from basalts of the inner floor ${ }^{11}$ and those from the Rift Mountain Region ${ }^{12}$ of the Rift Valley.

lig. 2 A profile drawn from a multic hannel narrow beam survey chart made in the sampled area located near station $\mathrm{CH} 77-07$ on the Sierra Leone Rise

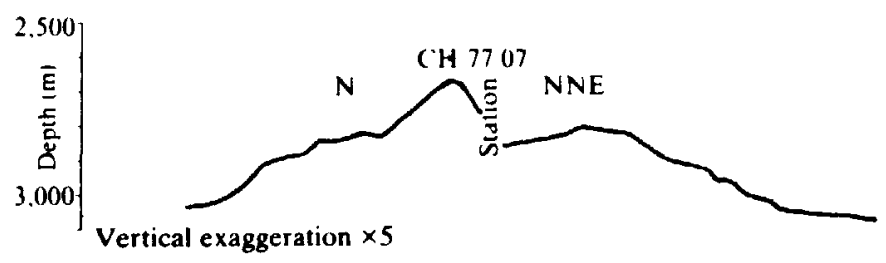

Because of the extended degree of alteration in the groundmass, the chemical analyses of the latter did not give any indication of the nature of the rock. However, microprobe (EDAX) analyses of the unaltered feldspar suggest the alkaline character of the samples.

The composition of the feldspar is indicated in Table 1 and shown on a ternary diagram (or-ab-an) in Fig. 3. The potassic and the sodic $\left(o r_{1}, a_{56} a_{n_{41.4}}-o r_{73} a_{766} a_{n_{16}}\right.$ ) nature of the feldspathic phases differs considerably from that found on the accreting plate boundary of the Mid-Atlantic Ridge (Fig. 3). The molecular percentage of orthoclase in the feldspar from the MAR basalts is insignificant ${ }^{11.12}$ when compared with that of the Sierra Leone Rise. However, there is a similarity in the composition of the Sierra Leone Rise (Fig. 3) feldspar to the alkaline volcanic series from oceanic islands (such as Hawaii, Saint Helena and Gough islands) (Fig. 3). In addition, the mineral composition and the textural features of the rocks from the Sierra Leone Rise suggest the trachyandesite type of volcanism encountered on the Walvis Ridge ${ }^{4}$. The feldspar analysed from the Walvis Ridge alkali basalt (sample WD 3-4) is also of a potassic nature (or ${ }_{40} \mathrm{ab}_{459} \mathrm{an}_{50}{ }_{1}-\mathrm{or}_{2.4} \mathrm{ab}_{28.6} \mathrm{an}_{69.0}$ ) like that from the Sierra Leone Rise (Fig. 3).

In conclusion, both the study of the clay fraction and the rock fragments demonstrate that we have sampled an extremely weathered volcanic outcrop near the top of one of the seamounts of the Sierra Leone Rise. This outcrop is covered by a thin intensely reworked carbonate ooze including Eocene to Palaeocene fauna, overlying a phosphate epigenised foraminiferal chalk of unknown age. This suggests that the last eruptive phase recorded in the sampling area occurred $4.5 \mathrm{Myr} \mathrm{BP}$, and gave rise to fractionated volcanics of an alkaline nature.

We thank the Captain and crew of the RV Jean Charcot for their help and J. Devineau for the sedimentological study done at the Centre des Faibles Radioactivités, Gif-sur-Yvette.

\section{R. HÉKINIAN}

Centre Océanologique de Bretagne,

BP 337, 29273 Brest Cedex, France

\section{P. BONTE \\ W. DUDLEY \\ P. L. BLANC \\ C. JEHANO \\ L. LABEYRIE \\ J. C. DUPLESSY}

Centre des Faibles Radioactivités, Laboratoires mixte CNRS-CEA, 91190 Gif-sur-Yvette, France

Received 13 June; accepted 4 August 1978

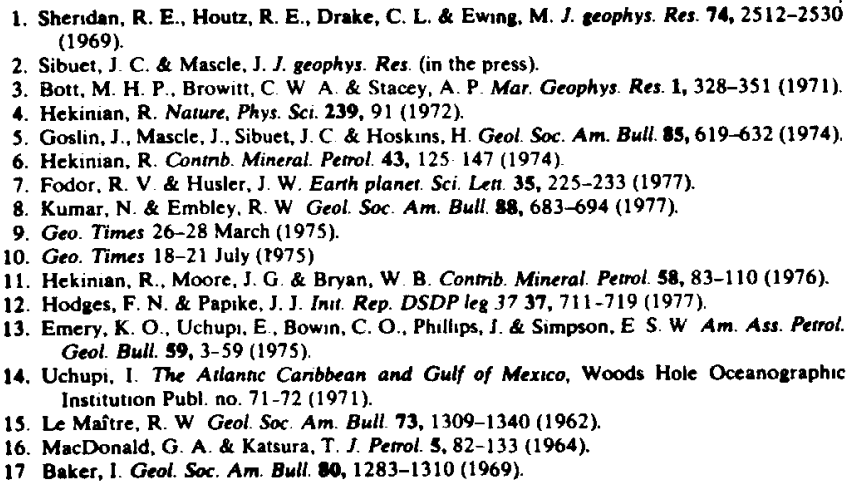

